\title{
The Structure and Formation of Lomasomes
}

\author{
By I. B. HEATH* AND A. D. GREENWOOD \\ Department of Botany and Plant Technology, Imperial College, London, S.W.7
}

(Accepted for publication I7 April 1970)

\section{SUMMARY}

Saprolegnia ferax and Dictyuchus sterile contain lomasomes and plasmalemmasomes whose structure and distribution are described. It is suggested that plasmalemmasomes are produced when plasmalemma production is not balanced by cell expansion. When plasmalemmasomes become sequestered in developing cell walls they may be termed lomasomes.

\section{INTRODUCTION}

The term lomasome was coined by Moore \& McAlear (196I) and defined by them as a 'dome shaped sponge-like intumescence', 'contiguous with the wall' containing 'granular or vesicular' material interiorly bounded by the plasmalemma. Structures conforming to this definition have since been reported frequently in walled cells. Their reported distribution and supposed functions have been reviewed by Bracker (I967) and also by Marchant \& Robards (I968), who attempted to provide a comprehensive account of their formation and suggested a new nomenclature. This is not applicable to all situations in which lomasomes have been reported and is frequently difficult to apply.

The present work was undertaken to describe the development of lomasomes in Saprolegnia ferax and Dictyuchus sterile and to account for their universal but variable occurrence in walled cells.

\section{METHODS}

Vegetative colonies of Saprolegnia ferax (Gruithuisen) Thuret and Dictyuchus sterile Coker were grown aseptically on the following medium (w/v): glucose, $\mathrm{I} \%$; peptone, $0 . \mathrm{I} \%$; yeast extract, $0.0 \mathrm{I} \% ; \mathrm{KH}_{2} \mathrm{PO}_{4}, 0 . \mathrm{I} \% ; \mathrm{MgSO}_{4} .7 \mathrm{H}_{2} \mathrm{O}, 0.03 \%$; and agar, $\mathrm{I} .5 \%$, in distilled water. Colonies grown in this medium without agar were induced to form zoospores by transfer to water. Zoospores were collected and germinated in the above medium. Vegetative colonies were grown at $10^{\circ}, 25^{\circ}, 30^{\circ}$ and $37^{\circ}$ whilst zoospores were produced at about $20^{\circ}$.

Fixation was in $2 \%(\mathrm{w} / \mathrm{v})$ potassium permanganate for $\mathrm{I} h$., or $1 \%(\mathrm{w} / \mathrm{v})$ osmium tetroxide for $\mathrm{I} h$., or $2.5 \%(\mathrm{w} / \mathrm{v})$ or $5 \%(\mathrm{w} / \mathrm{v})$ glutaraldehyde for $2 \mathrm{~min}$. to $2 \mathrm{~h}$. followed by I $\%$ osmium tetroxide for I $h$. All fixatives were buffered in $\mathrm{M} / \mathrm{I} 5$ Sorensen's phosphate at $\mathrm{pH} 7 \cdot 0$. All samples were dehydrated in ethanol and embedded via epoxypropane in Epon 812 . Unless stated otherwise, all sections illustrated were stained in $2 \%$ uranyl acetate $(20$ min.) followed by Reynolds' lead citrate $(7 \mathrm{~min}$.). Vegetative colonies were fixed in situ on the agar, and single apices were selected with the aid of an optical microscope from the advancing edge of the embedded colony and sectioned in a

* Present address: Department of Botany, University of Georgia, Athens, Georgia 30601, U.S.A.

Vol. 62, No. I was issued 12 October 1970 
known orientation. Other stages in the life cycle were also selected by optical microscopy from the embedded material.

Some sections of material fixed in glutaraldehyde-osmium were mounted on gold grids and treated with the periodic acid-silver hexamine stain (PASH) described by Pickett-Heaps (1967) in order to reveal areas with a high concentration of polysaccharide. Thirty min. in I \% periodic acid followed by $\mathrm{I} h$. in silver hexamine, both at $60^{\circ}$, gave satisfactory results (Heath, 1969).

Fresh hyphae were incubated in IOO $\mu \mathrm{M}$ 4-acetamido-4'-isothiocyanato-stilbene2,2' disulphonic acid, disodium salt (SITS: (B.D.H. Ltd, Poole, Dorset) dissolved in M/I 5 phosphate buffer at $\mathrm{pH} 7.0$ for Io min. briefly rinsed, then mounted in the above buffer. These hyphae were examined using phase contrast and fluorescence contrast (Reichert filters $\mathrm{E}_{4}$ and $\mathrm{Sp}$ I). Some hyphae were stained with SITS as above, and then observed while the preparation was irrigated with $5 \%$ glutaraldehyde or I \% osmium tetroxide, both phosphate buffered. Some growing hyphae were plasmolysed in $2 \mathrm{M}$ sucrose and examined by phase contrast.

\section{RESULTS}

'Lomasome' will be used to refer to membranous vesicular material embedded in the wall external to the line of the plasmalemma, and 'plasmalemmasome' will refer to the various membrane configurations which are external to the plasmalemma, often in a pocket projecting into the cytoplasm, and less obviously embedded in wall material. Since there is a gradation between them these terms will be used for convenience only. Zoosporogenesis in Saprolegnia ferax has been described by Gay \& Greenwood (1966), whose paper should be consulted for a detailed description of this process and the associated terminology. The process in Dictyuchus sterile is similar except that primary spores are not liberated; they encyst within the sporangium and later produce exit papillae through which they release secondary zoospores.

In Saprolegnia ferax lomosames occurred at the apices (typically 0 to $20 \mu \mathrm{m}$.) of growing vegetative hyphae (Pl. I, fig. I; Pl. 2, fig. 4) but not in old hyphal walls; in developing, but not mature, apical papillae and in the side walls of the developing and discharged sporangia (Pl. I, fig. 2; Pl. 3, fig. 7). In the sporangial walls (Pl. I, fig. 2) they sometimes contained cytoplasm and ribosomes which were absent in the other locations. Lomasomes also occurred in the walls of encysted spores ( $\mathrm{Pl}$. 8, fig. 21) but they were less abundant there than in hyphal apices.

The structure of lomasomes did not detectably differ whether fixed by osmium tetroxide or glutaraldehyde and they still appeared vesicular after fixation with potassium permanganate. The vesicles of some lomasomes were near the outer surface of the wall and appeared to be in the process of being sloughed off (Pl. 3, fig. 6, 7).

Dictyuchus sterile was examined less extensively than Saprolegnia ferax but again lomasomes occurred in regions of wall synthesis, namely in the walls of the primary spores and in their exit papillae (Pl. 4, fig. 9, I0).

In all these situations the size and abundance of lomasomes was very variable; they were often absent. In both species another type of lomasome was always found in the cross walls at the bases of sporangia. These lomasomes differed from other lomasomes in having more irregular membranes which were always associated with cytoplasm and ribosomes and, occasionally, lipid droplets (Pl. 5, fig. II, I2). 
An ontogenetically different type of lomasome occurred in intrahyphal hyphae (Lowry \& Sussman, I966) where one hyphal apex was found growing through an apparently dead hypha. In such apices, lomasomes were frequently found between the walls of the young and old hyphae (Pl. 2, fig. 5) where the membranes of the old hypha apparently became pressed against the outer wall by the expanding inner one.

The distribution of plasmalemmasomes closely followed that of lomasomes and when present their abundance was equally variable. Their structure was more variable than that of lomasomes, ranging from well defined depressions of the plasmalemma, about $\mathrm{I} \mu \mathrm{m}$. deep, closely packed with variously sized vesicles and tubules (Pl. 3, fig. 6; P1. 6, fig. I3; Pl. 8, fig. 21) to long shallow depressions loosely filled with tubular membranes (Pl. I, fig. 3; Pl. 2, fig. 4; Pl. 6, fig. 14). Connexions between these tubules and vesicles and the plasmalemma was rare but did occur (Pl. I, fig. 3). There was perhaps a morphological sequence from tubules not embedded in wall material (PI. I, fig. 3; Pl. 6, fig. I4) to vesicles which appeared to become progressively sequestered in the wall (Pl. 3, fig. 6; Pl. 6, fig. I3). Such structures as those in Pl. 6, fig. I3 were morphologically transitional between plasmalemmasomes and lomasomes. The vesicles of this transitional stage were embedded in material which reacted like the cell wall to uranyl acetate and lead citrate staining (Pl. 6, fig. 13) and PASH treatment (Pl. 8, fig. 21). Both types of material were sometimes associated with a type of staining deposit which occasionally appeared specifically on cell walls after uranyl acetate and lead citrate staining (Pl. 6, fig. I 5).

The primary cysts and exit papillae of Dictyuchus sterile contained typical plasmalemmasomes (Pl. 4, fig. 9, Io) but they also contained simpler elaborations of the plasmalemma which were not tubular or vesicular (Pl. 4, fig. 8).

Plasmalemmasomes were poorly preserved by potassium permanganate fixation, but both vesicular and tubular forms were found after glutaraldehyde fixation (P1. 6, fig. 13), even after only 2 min. fixation (Pl. 2, fig. 4), and after osmium tetroxide fixation (P1. 6, fig. 14). However, some apices, fixed in osmium tetroxide only, lacked tubular plasmalemmasomes but had corresponding areas containing irregular membranes some of which were connected to the plasmalemma (PI. 7, fig. I6, I7). Such areas were not found in glutaraldehyde fixed material nor did they occur in hyphae with tubular or vesicular plasmalemmasomes.

The size and composition of plasmalemmasomes and lomasomes and their proximity to the highly refractile cell wall did not favour their detection by bright field or phase contrast optical microscopy although the structures seen with the electron microscope were frequently of a size above the limit of resolution of the optical microscope. Maddy (1964) developed a fluorescent stain (SITS) which was claimed to bind to specific sites in the plasmalemma. Since part of the specificity of this stain was its inability to penetrate the permeability barrier (Maddy, I964), it was reasoned that it might also stain lomasomes and plasmalemmasomes which are membranous structures external to the plasmalemma.

Application of SITS caused instantaneous cessation of cytoplasmic movement, but hyphae which were fixed with glutaraldehyde and osmium tetroxide and examined with the electron microscope after incubation in SITS showed an apparently normal structure, including plasmalemmasomes. The only difference detected between SITS treated and normal hyphae was the occurrence, in the nuclei, of fibrils comparable to those reported by Robbins \& Gonatas (1964) in colchicine-treated HeLa cells. 
Similar fibrils were not usually found in Saprolegnia ferax, except after colchicine treatment (Heath, 1969); their presence after SITS staining and the cessation of cytoplasmic movement were evidence that at least part of the SITS molecule penetrated into the cell.

All structures examined showed negligible autofluorescence, but after incubation in SITS a strong pale blue fluorescence was detected in all hyphae. It was most intense at the apex of the hyphae and decreased gradually to a constant intensity subapically (Pl. 9, fig. 25, 27). While the distribution of fluorescence was often even, it sometimes occurred in diffuse patches in hyphal apices (Pl. 9, fig. 25, 27), the walls of discharged sporangia (PI. I0, fig. 28) and in intrahyphal hyphae apices (Pl. I0, fig. 29). Addition of fixatives did not alter the distribution of SITS but caused a gradual fading of fluorescence. SITS did not stain plasma membranes only; cell walls of Saprolegnia ferax (P1. 8, fig. 23), elder pith, and pea leaf cell walls showed a strong fluorescence. In the pea leaf tissue fluorescence was strongest in the spiral thickening of the xylem cells.

When hyphae were plasmolysed the subapical cytoplasm became contracted, often into bead-like masses in the centre of the hyphae (P1. 8, fig. I9), but apical cytoplasm was not observed to contract or separate from the cell wall (P1. 8, fig. 18, 19).

Apices of Saprolegnia ferax grown at $10^{\circ}$ and $25^{\circ}$ contained lomasomes and plasmalemmasomes (Pl. I, fig. I); the variation in these structures between apices grown at these two temperatures was no greater than that found between apices from a single colony. Colonies grown at $30^{\circ}$ had a slightly higher growth rate than those grown at $25^{\circ}$, yet four out of the five apices examined from these colonies contained a highly characteristic organization, a feature of which was the vesicular material lying between the plasmalemma and the cell wall (Pl. 8, fig. 20). Such elaborations sometimes extended from the apex to at least $70 \mu \mathrm{m}$. along the hyphae. Lomasomes were not detected in hyphae grown at $30^{\circ}$.

We did not observe structures comparable to the multivesicular bodies described by Marchant, Peat \& Banbury (1967) and Marchant \& Robards (1968).

\section{DISCUSSION}

It has been suggested that plasmalemmasomes and lomasomes may be artefacts produced by the fixatives used for electron microscopy (Bracker, 1967). But the lomasomes described in the present paper had a similar structure after all the fixations employed. Furthermore, because cell walls are relatively rigid structures, material such as lomasomes is unlikely to become embedded in them as a fixation artefact. Finally, although the SITS reagent stained both walls and plasmalemma, the areas of increased fluorescence in the walls of discharged sporangia and intrahyphal hyphal apices were probably due to accumulations of membranes within the walls. This also suggests that lomasomes occur in vivo and that they are composed of membranous vesicles. Clearly a freeze-etch investigation will provide the most convincing proof for the existence in vivo of lomasomes.

A convincing demonstration of plasmalemmasomes is difficult, but the presence of similar structures after three types of fixation, together with the diffuse patches of SITS stain in PI. 9, fig. 25, supports the hypothesis that plasmalemmasomes occur in vivo. The plasmolysis experiments suggest a closer association between the cyto- 
plasm and the apical wall as compared with the subapical regions, an observation consistent with the close interrelationship between plasmalemma and wall material in the apical plasmalemmasomes observed in many electron micrographs.

Marchant \& Robards (1968) have suggested that multivesicular bodies, originating from the endoplasmic reticulum, pass through the plasmalemma and become lomasomes. Multivesicular bodies do not occur in either Saprolegnia ferax or Dictyuchus sterile, so cannot be involved in lomasome synthesis in these species.

Boundary formations (Esau, Cheadle \& Gill, 1966) or paramural bodies (Marchant \& Robards, I968), to use two general terms which encompass both lomasomes and plasmalemmasomes, have only been reported in walled cells where they are most frequently found in areas active in wall synthesis (see reviews by Bracker, 1967, and Marchant \& Robards, 1968). Cell walls are usually synthesized in part from vesicles which fuse with the plasmalemma (Mühlethaler, 1967; Northcote, 1969). There is evidence (Heath, 1969) for vesicular activity in wall synthesis in both Saprolegnia ferax and Dictyuchus sterile at all sites where lomasomes have been described in the present work. The fusion of vesicles with the plasmalemma may be expected to increase its area. Robertson (1958) has shown that hyphal extension is a result of the interaction between wall plasticity and turgor pressure. We suggest that plasmalemmasomes are produced when this balance is disturbed so that more plasmalemma is produced than is needed to line the cell wall, and that the plasmalemmasomes may become sequestered in the developing wall thus producing lomasomes. On the basis of Pl. 3, fig. 6 and 7 , the absence of lomasomes in old hyphal walls and mature apical papillae is accounted for by changes in the cell wall resulting in the sloughing off of the lomasomes. Whether large structures are able to move within developing cell walls has been discussed by Mühlethaler (1967).

Some factors which may contribute to the balance between cell expansion and membrane production are the control of wall plasticity and tugor pressure, the relative quantities of vesicle-contributed versus surface-synthesized wall material, and the activity of a system capable of removing subunits from the plasmalemma thus reducing its area. The existence of the latter system is clearly shown in the encysting primary spores of both Dictyuchus sterile and Saprolegnia ferax. In both cases the wall is thickened by the addition of vesicle-enclosed material (Heath, 1969), presumably with the concurrent addition of membrane to the plasmalemma, yet since the spores of $D$. sterile encyst within the sporangia and those of $S$. ferax do not increase their diameter during cyst development, the cell cannot expand to accommodate the additional membrane. In these spores plasmalemmasomes and lomasomes do occur, but as they are apparently not universal some mechanism must reduce the area of the plasmalemma.

The nature of the membranous material external to the plasmalemma in the apices grown at $30^{\circ}$ is not fully understood, but by its position it appears to be equivalent to plasmalemmasomes and indicates that temperature fluctuation may be another possible cause of variability in lomasome abundance. The small temperature changes which occur when colonies are removed from the incubator and placed in fixative may be sufficient to produce an imbalance leading to plasmalemmasomes. Ehrlich, Schafer \& Ehrlich (I968) also noted that growth temperature affected the abundance of lomasomes.

Not all causes of an imbalance need be considered 'abnormal'. For example, there 
must be variations in the growth rate of an individual hypha such as to allow branch apices to reach the margin of the colony then grow more slowly to stay level with the other apices. Such changes may easily result in the formation of lomasomes.

The configuration assumed by the excess plasmalemma remains uncertain in the absence of freeze-etch studies of unfixed cells, but the vesicular nature of the membranes in the lomasomes (which are unlikely to be altered by fixation, see above) suggests that the plasmalemmasomes become vesicular before sequestration. The tubular forms are comparable to the membranous configurations reported in other situations, e.g. Thomas \& Isaac (1967), and probably represent a stage which may be assumed in vivo before they break down to vesicles. The irregular membranes found occasionally after osmium tetroxide fixation (Pl. 7, fig. I6, I7) may well be artefacts produced by the disruption of tubular/vesicular plasmalemmasomes (cf. FranziniArmstrong \& Porter, 1964; Tormey, 1964).

The tendency for membranes to become vesicular before sequestration is also shown in the lomasomes of the intrahyphal hyphae apices, although the membranes here are probably the remaining general cytoplasmic membranes of the old hypha. The sequestered membrane of the sporangial cross walls is usually less regularly vesicular. Such irregularities may be a function of the speed of insertion of this wall. Rothert (I888) and Gay \& Greenwood (I966) show that the cross wall of Saprolegnia ferax is inserted in a few seconds.

That plasmalemmasomes can arise from elaborations of the plasmalemma has been shown by other authors, e.g. Becking, De Boer \& Houwink (1964) and Marchant \& Robards (1968), but their production due to an imbalanced system and their subsequent sequestration to form lomasomes has not previously been suggested. The present hypothesis first accounts for the restriction of plasmalemmasomes to walled cells. Naked cells would presumably expand to maintain a smooth plasmalemma unless restricted by underlying structures. It also predicts their occurrence primarily in areas of wall synthesis, as is observed by most authors. This hypothesis appears to fit all reported lomasomes and plasmalemmasomes with the exception of the 'flecks' which Barton (1965) suggested do not form from 'charasomes' in Chara. It further implies that boundary formations have no specific function although they may represent sites of high activity of plasmalemma-bound enzymes (Mühlethaler, 1967). It also alleviates the problem encountered by most authors in ascribing a function to such a variable structure which is not found specifically associated with any definable process.

Plasmalemmasomes and lomasomes are perhaps to be recognized as consequences of basic similarities of organization in walled eukaryotic cells rather than to be thought of as specific fungal structures as suggested by Moore \& McAlear (I96I), who first defined the term 'lomasome'. Superficially plasmalemmasomes are similar to bacterial mesosomes (e.g. van Iterson \& Leene, I 964), but these structures are functionally well-characterized organelles probably of an entirely different nature to the plasmalemmasomes, for which reason we have not considered them here.

The authors wish to acknowledge numerous helpful discussions with Dr J. L. Gay and Dr M. S. Fuller. We thank the S.R.C. for a Studentship to one of us (I. B.H.). This work was submitted in part fulfilment of the requirements of the Ph.D. degree of the University of London. 


\section{REFERENCES}

BARTON, R. (1965). Electron microscope studies on surface activity in cells of Chara vulgaris. Planta 66, 95-I05.

BECKING, J. H., DE BOER, W. E. \& HouwINK, A. L. (1964). Electron microscopy of the endophyte of Alnus glutinosa. Antonie van Leeuwenhoek 30, 343-376.

BRACKER, C. E. (1967). Ultrastructure of fungi. Annual Review of Phytopathology 5, 343-374.

EhrLich, M. A., SchafER, J. F. \& EhrLich, H. G. (1968). Lomasomes in wheat leaves infected by Puccinia graminis and $P$. recondita. Canadian Journal of Botany 46, 17-20.

Esau, K., Cheadle, V. I. \& Gill, R. H. (1966). Cytology of differentiating tracheary elements. II. Structures associated with cell surfaces. American Journal of Botany 53, 765-771.

Franzini-Armstrong, C. \& Porter, K. R. (1964). Sarcolemmal invaginations constituting the $\mathrm{R}$ system in fish muscle fibres. Journal of Cell Biology 22, 675-696.

GAY, J. L. \& Greenwood, A. D. (1966). Structural aspects of zoospore production in Saprolegnia ferax with particular reference to the cell and vesicular membranes. In The Fungus Spore, Proceedings I8th Colston Research Society Conference, pp. 95-1 10. Edited by M. F. Madelin. London: Butterworths.

Heath, I. B. (1969). Structural Aspects of the Growth and Reproduction of Saprolegnia spp. Ph.D. Thesis, University of London.

VAN ITERSON, W. \& LeENE, W. (1964). A cytochemical localization of reductive sites in a Gram-positive bacterium. Tellurite reduction in Bacillus subtilis. Journal of Cell Biology 20, 36ז-375.

Lowry, J. R. \& SUSSMAN, A. S. (1966). Intrahyphal hyphae in 'clock' mutants of Neurospora. Mycologia 58, 541-548.

MADDY, A. H. (I964). A fluorescent label for the outer components of the plasma membrane. Biochimica et Biophysica Acta 88, 390-399.

Marchant, R., Peat, A. \& Banbury, G. H. (1967). The ultrastructural basis of hyphal growth. New Phytologist 66, 623-629.

MARChANT, R. \& Robards, A. W. (1968). Membrane systems associated with the plasmalemma of plant cells. Annals of Botany 32, 457-47I.

MoORE, R. T. \& MCAlEAR, J. H. (1961). Fine structure of mycota. 5. Lomasomes-previously uncharacterized hyphal structures. Mycologia 53, I94-200.

MÜHLETHALER, K. (1967). Ultrastructure and formation of plant cell walls. Annual Review of Plant Physiology 18, I-24.

NoRTHCOTE, D. H. (1969). Fine structure of cytoplasm in relation to synthesis and secretion in plant cells. Proceedings of the Royal Society of London, Series B, 173, 2I-30.

Picketr-Heaps, J. D. (1967). Preliminary attempts at ultrastructural polysaccharide localization in root tip cells. Journal of Histochemistry and Cytochemistry 15, 442-455.

RobBins, E. \& Gonatas, N. K. (1964). Histochemical and ultrastructural studies on HeLa cell cultures exposed to spindle inhibitors with special reference to the interphase cell. Journal of Histochemistry and Cytochemistry 12, 704-71 I.

Robertson, N. F. (1958). Observations on the effect of water on the hyphal apices of Fusarium oxysporum. Annals of Botany 22, I59-173.

RotheRT, L. (1 888). Die Entwicklung der Sporangien bei den Saprolegnium. Beiträge zur Biologie der Pflanzen 5, 291-349.

ThомAS, P. L. \& IsAAC, P. K. (1967). An electron microscope study of intravesicular bodies in the uredia of wheat stem rust and in hyphae of other fungi. Canadian Journal of Botany 45, 1473-1478.

ToRMEY, J. MCD. (1964). Differences in membrane configuration between osmium tetroxide-fixed and glutaraldehyde-fixed ciliary epithelium. Journal of Cell Biology 23, 658-664. 


\section{EXPLANATION OF PLATES}

Key to symbols: $\mathrm{P}=$ plasmalemmasome, $\mathrm{L}=$ lomasome, $\mathrm{v}=$ vesicles, which probably play a role in wall formation; $\mathrm{Ga}=$ fixed in glutaraldehyde followed by osmium tetroxide, $\mathrm{Os}=$ fixed in osmium tetroxide alone; $\mathrm{w}=$ wall, $\mathbf{H}=$ hypha, $\mathbf{M}=$ mitochondrion, $\mathrm{Va}=$ vacuole, $\mathbf{S}=$ sporangium, $\mathrm{xw}=$ cross wall, $\mathrm{Li}=$ lipid, $\mathrm{er}=$ endoplasmic reticulum, $\mathrm{N}=$ nucleus, $\mathrm{A}=$ apex.

\section{Plate I}

Fig. I. Saprolegnia ferax. Median longitudinal section of a vegetative hyphal apex grown at $25^{\circ}$. The accumulation of vesicles (v) is a characteristic of the apex. Note the abundant lomasomes and plasmalemmasomes. Ga. $\times$ I7,250.

Fig. 2. $S$. ferax. Lomasomes in a sporangium wall (w). Note the ribosomes (arrowed) with the membranes. Os. $\times 39,300$.

Fig. 3. S. ferax. Loosely arranged plasmalemmasome (P) with a connexion between the plasmalemma and a tubule (arrowed). Ga. $\times 84,500$.

\section{Plate 2}

Fig. 4. S. ferax. Transverse section of a vegetative hypha at approximately the level of line A. in PI. I, fig. I. Fixed for $2 \mathrm{~min}$. in Ga. Note the large tubular plasmalemmasome and numerous lomasomes. $\times 54,800$.

Fig. 5. S. ferax. Transverse section of a portion of an intrahyphal hypha. The apparently healthy hypha $(H)$ has an irregular wall $\left(\mathrm{w}_{1}\right)$ with a plasmalemmasome $(\mathbf{P})$. The cytoplasm of the old hypha (including a mitochondrion, $M$ ) is trapped between the young $\left(\mathrm{w}_{1}\right)$ and old $\left(\mathrm{w}_{2}\right)$ walls and has the morphological appearance of a lomasome. Ga. $\times 20,100$.

\section{Plate 3}

Fig. 6. S. ferax. Probable sequence of lomasome formation. A tubular plasmalemmasome (P) lies adjacent to a lomasome (L) with some vesicles (solid arrow) apparently becoming sequestered in the wall. The vesicles marked by an open arrow probably represent a 'sloughing off' process whereby lomasomes may be lost from the walls. This section was of the hyphal wall immediately below a sporangium cross wall. Ga. $\times 61,400$.

Fig. 7. S. ferax. Wall of a discharged sporangium (S) showing persistent lomasome in inner layer of wall and another lomasome $\left(L_{1}\right)$ apparently in the process of sloughing off. Ga. $\times 64,300$.

\section{Plate 4}

Fig. 8. Dictyuchus sterile. Wall between adjacent primary cysts. This wall is developing within a sporangium. Note the 'excess' membranes apparently connected to the plasmalemma (arrows). Ga. $\times 98,600$.

Fig. 9. D. sterile. Developing exit papillum of a primary cyst. The cyst wall $\left(\mathrm{w}_{1}\right)$ is extended through the sporangium wall $\left(\mathrm{w}_{2}\right)$. The cyst wall contains numerous lomasomes $(\mathrm{L})$ and there are prominent plasmalemmasomes, the apical one of which contains a dense body (Gay \& Greenwood, 1966). Ga. $\times 20,000$.

Fig. IO. D. sterile. Developing primary cyst wall $\left(\mathrm{w}_{1}\right)$ containing lomasomes and associated with plasmalemmasomes. The thick sporangium wall $\left(\mathrm{w}_{2}\right)$ prevents expansion of the cysts. Ga. $\times 24,800$.

\section{Plate 5}

Fig. I1. S. ferax. Centre portion of the basal cross wall of a sporangium showing the triple layered wall (xw) enclosing membranes, ribosomes and lipid (Li) between each layer. Os. $\times 30,200$.

Fig. I2. S. ferax. Cross wall (xw) at the base of a discharged sporangium (S). Sequestered cytoplasm is compressed to varying degrees. The accumulation of vesicles (v) probably marks a site of regrowth of the hypha which will result in the production of a new sporangium. Ga. $\times$ I4,850.

\section{Plate 6}

Fig. I3. S. ferax. A tubular-vesicular plasmalemmasome adjacent to a lomasome in a hyphal apex. The wall material appears to permeate the spaces between the vesicles at the outer side of the plasma- 

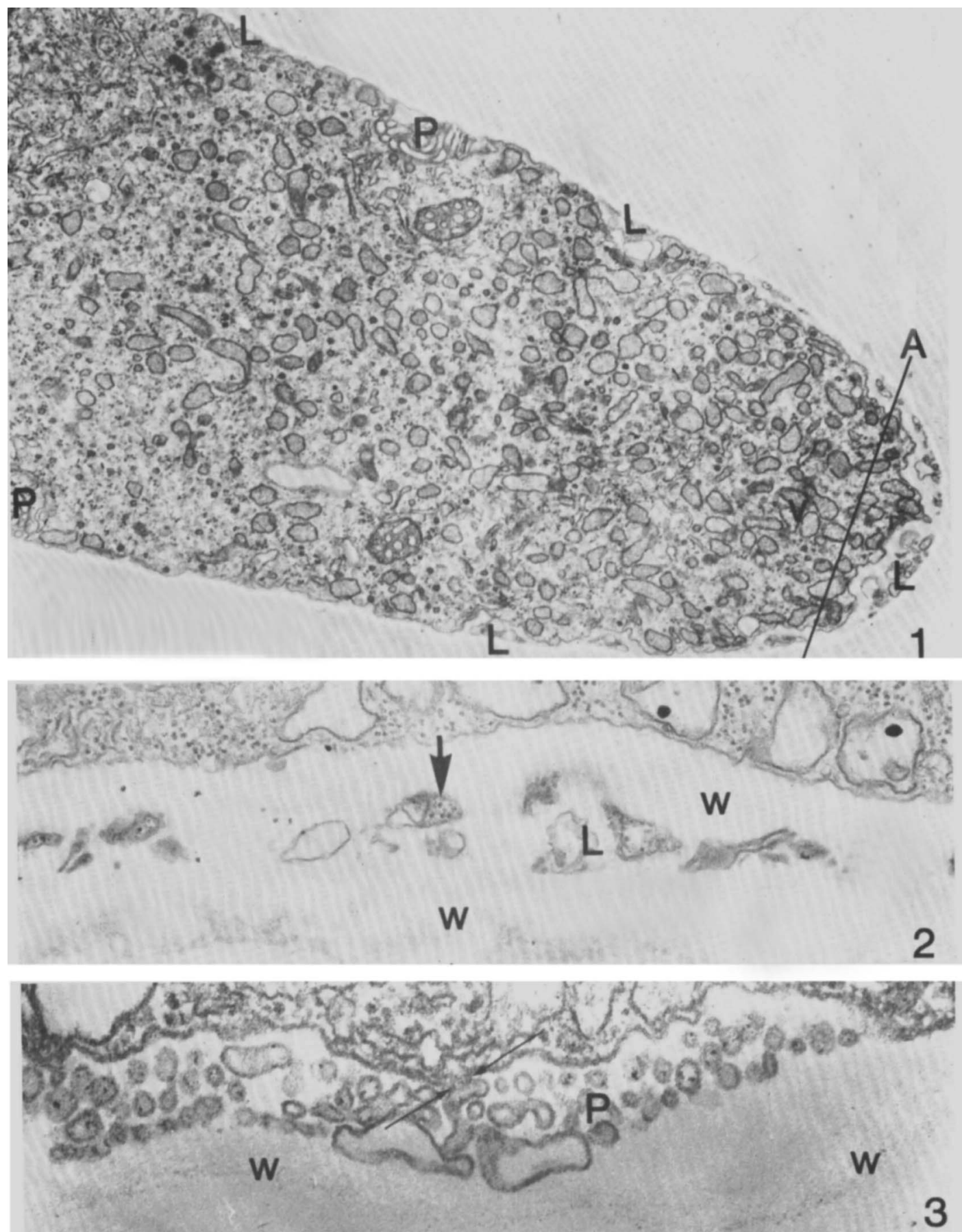


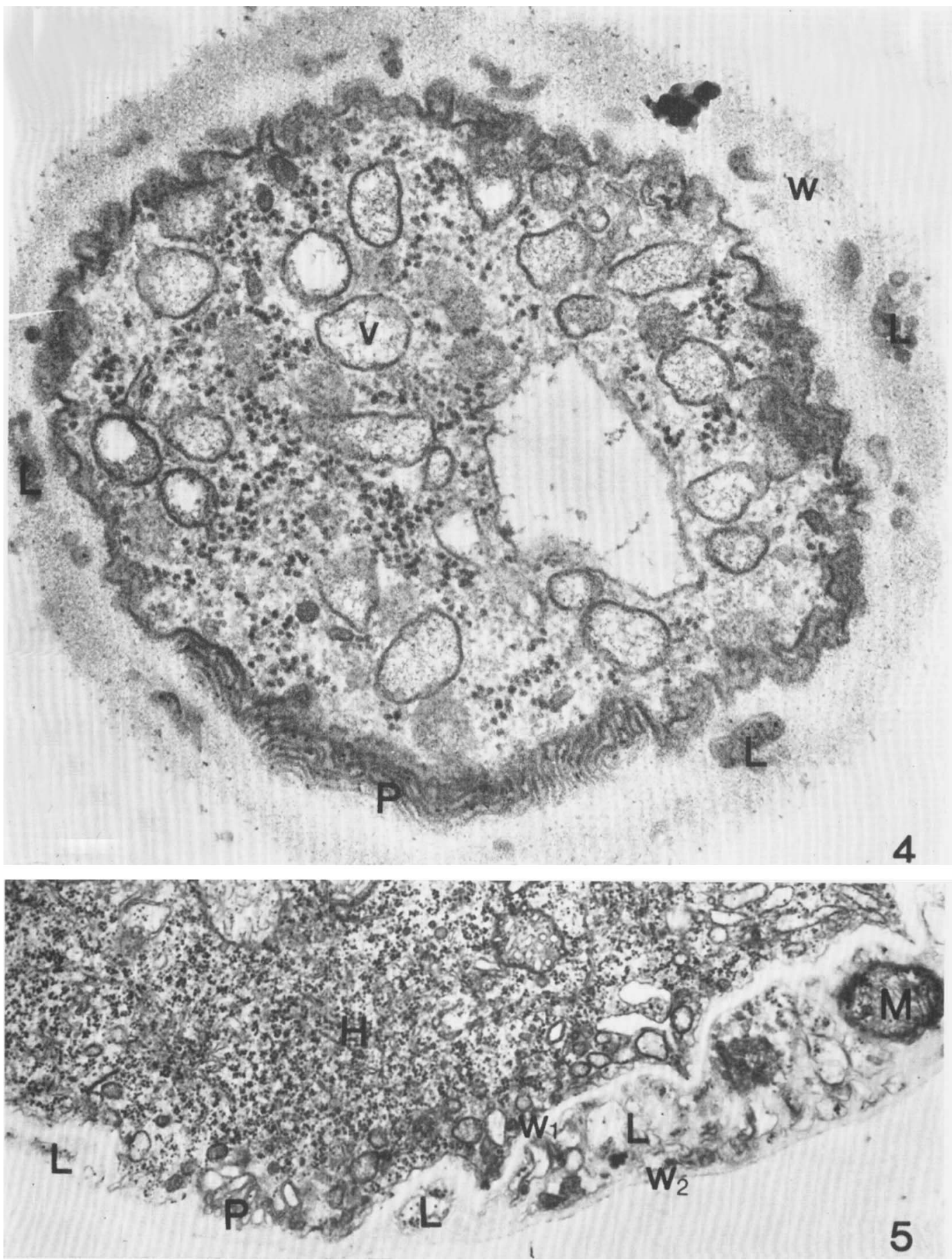

I. B. HEATH AND A. D. GREENWOOD 
Journal of General Microbiology, Vol. 62, No. 2

Plate 3

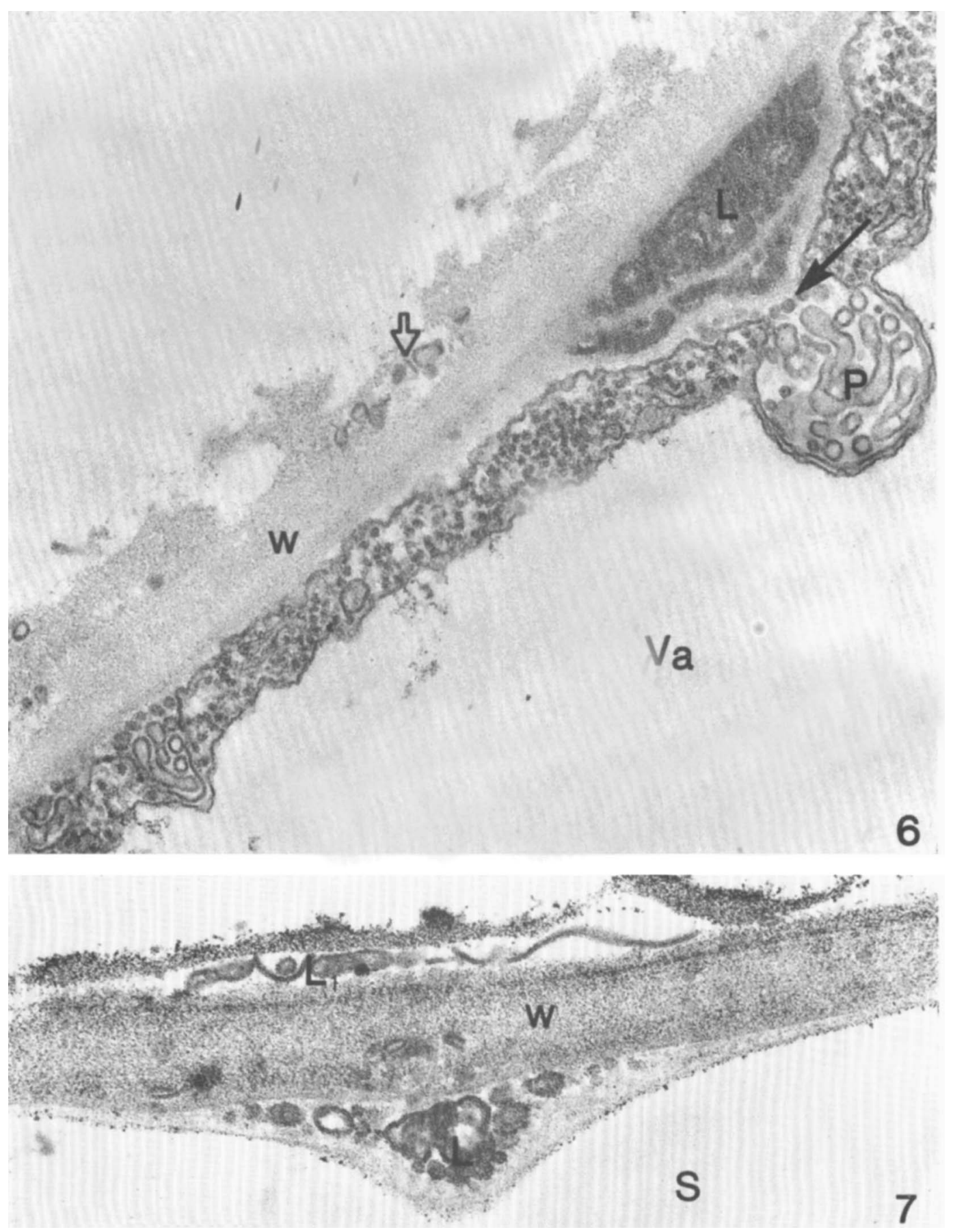

I. B. HEATH AND A. D. GREENWOOD 

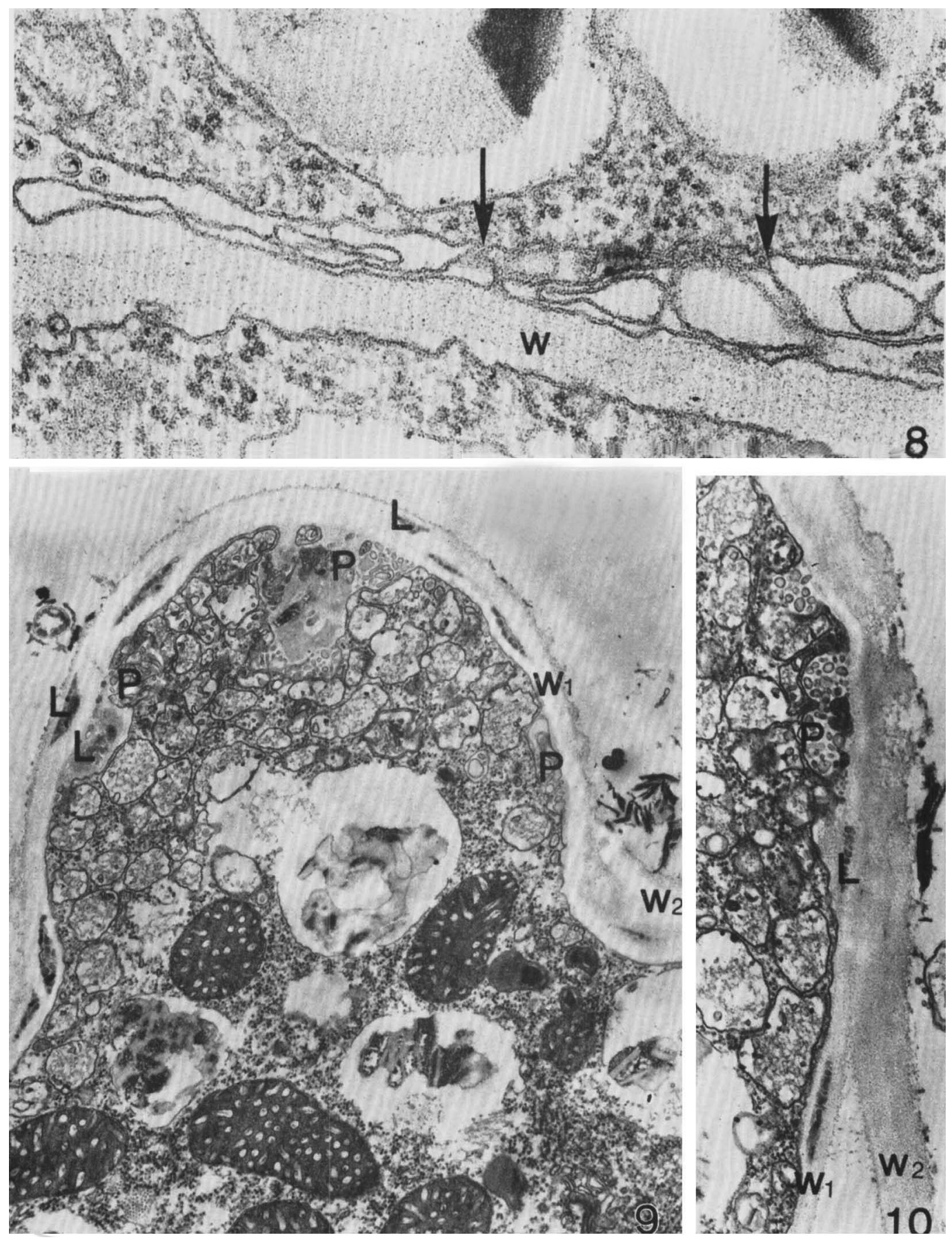

I. B. HEATH AND A. D. GREENWOOD 


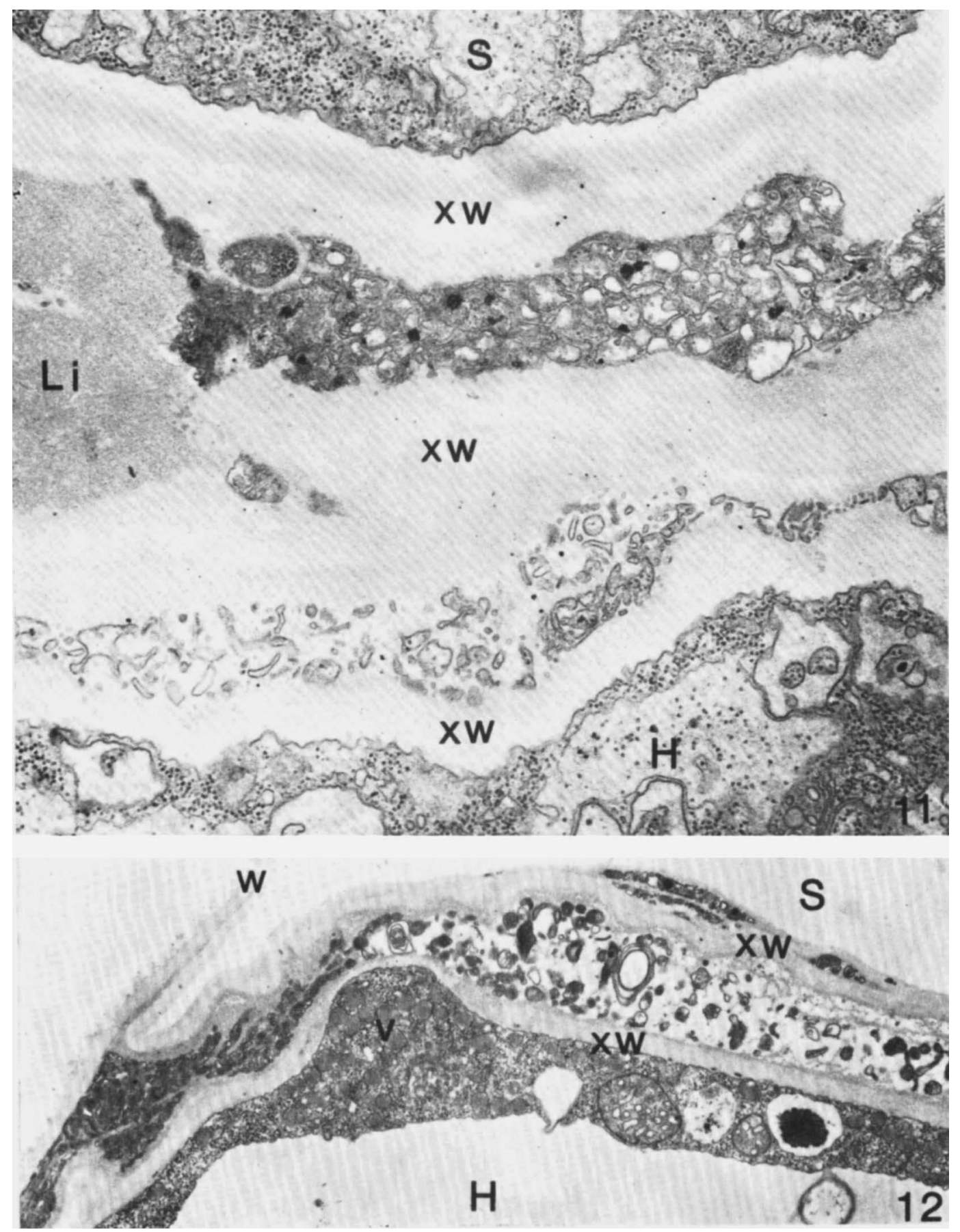

I. B. HEATH AND A. D. GREENWOOD 
Journal of General Microbiology, Vol. 62, No. 2

Plate 6
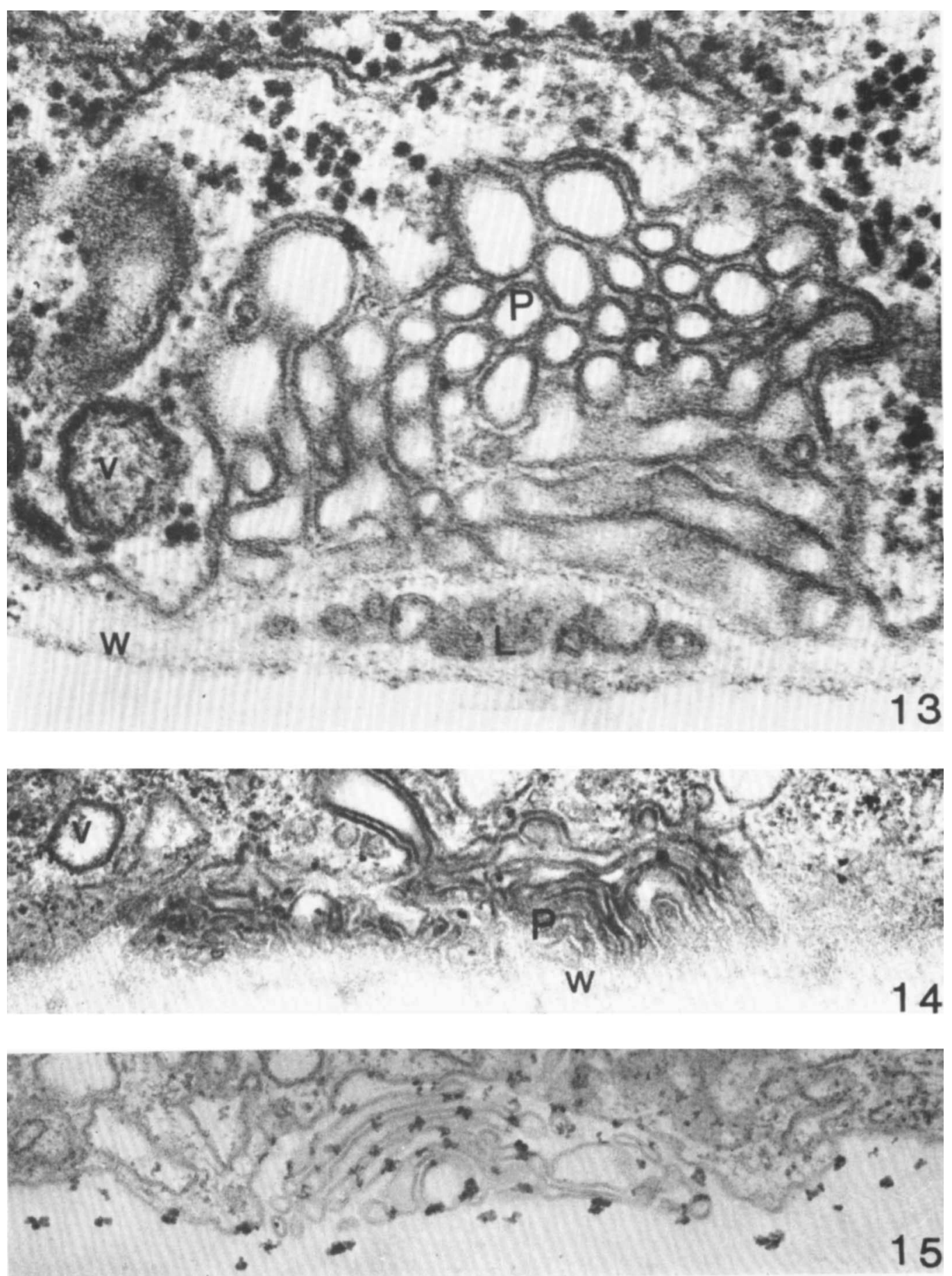

I. B. HEATH AND A. D. GREENWOOD 
Journal of General Microbiology, Vol. 62, No. 2

Plate 7
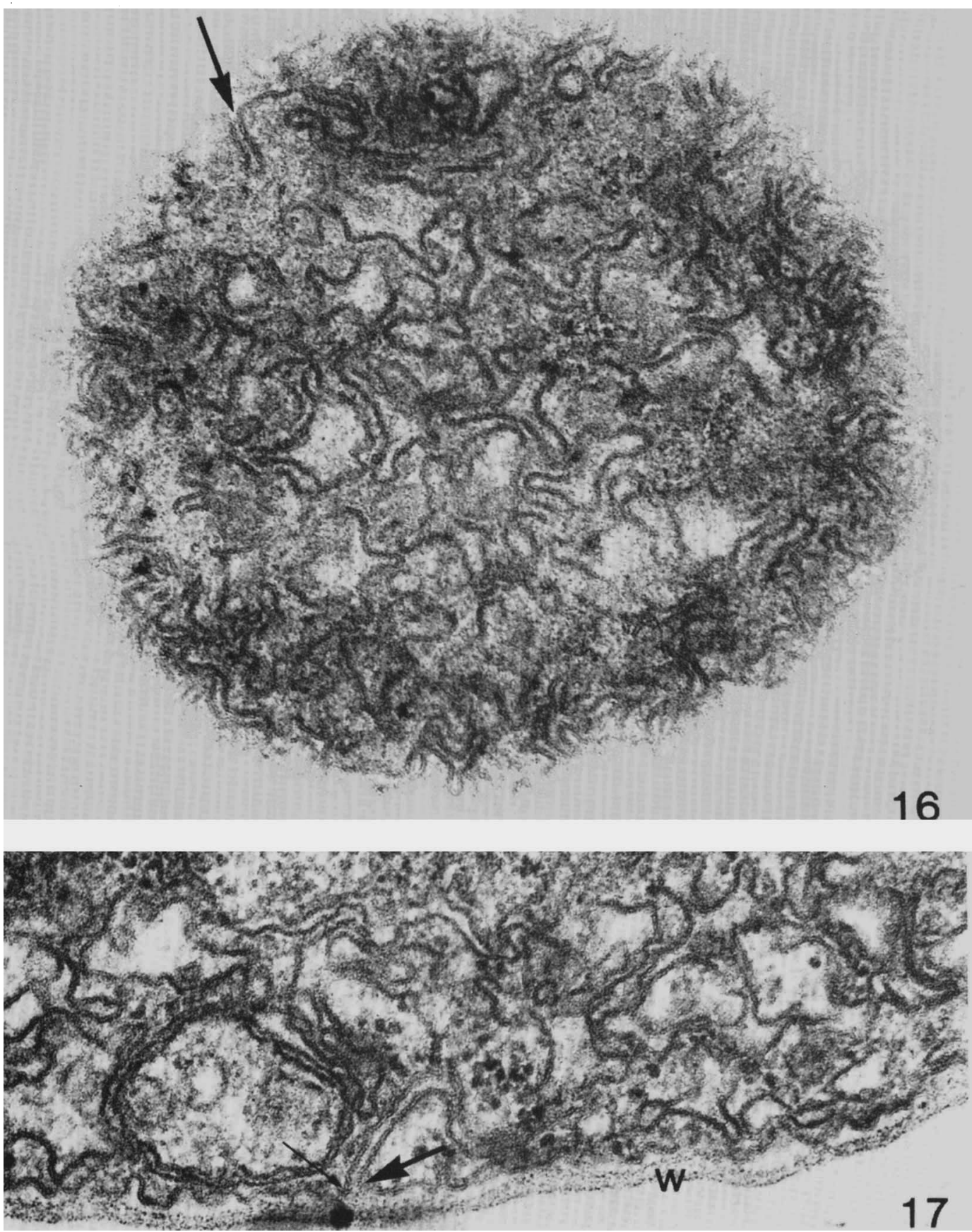

I. B. HEATH AND A. D. GREENWOOD 

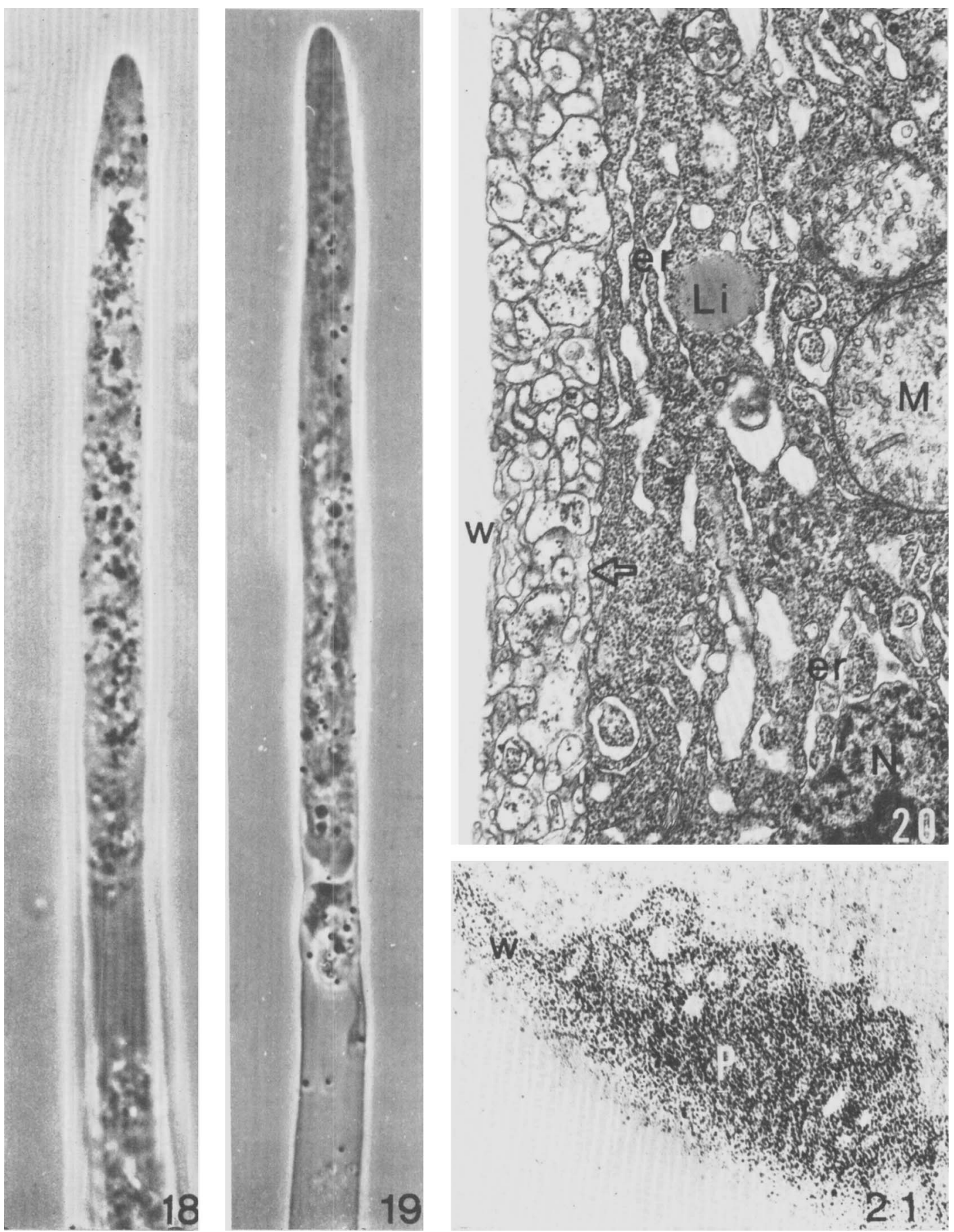

I. B. HEATH AND A. D. GREENWOOD 
Journal of General Microbiology, Vol. 62, No. 2

Plate 9
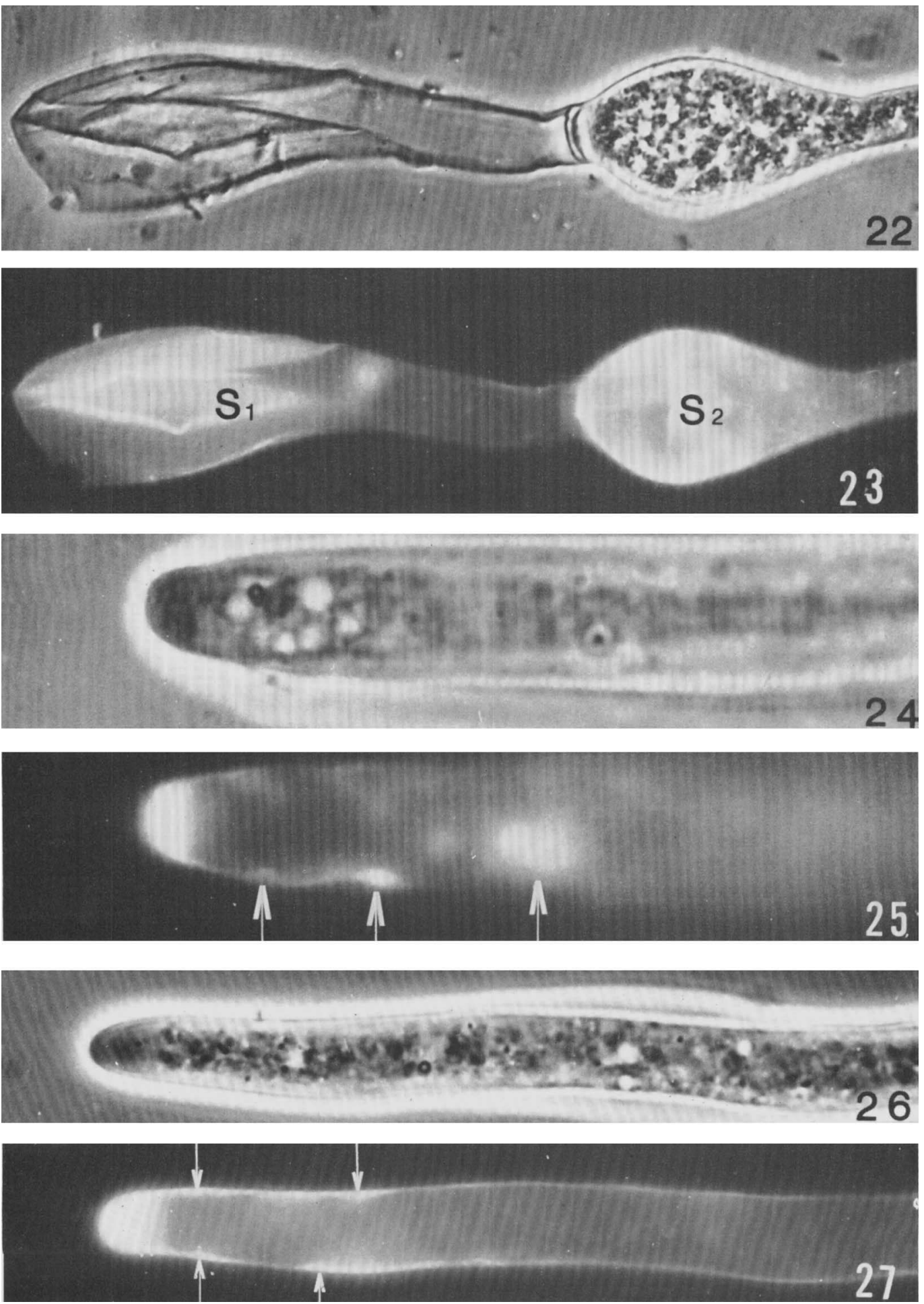

I. B. HEATH AND A. D. GREENWOOD 
Journal of General Microbiology, Vol. 62, No. 2

Plate 10
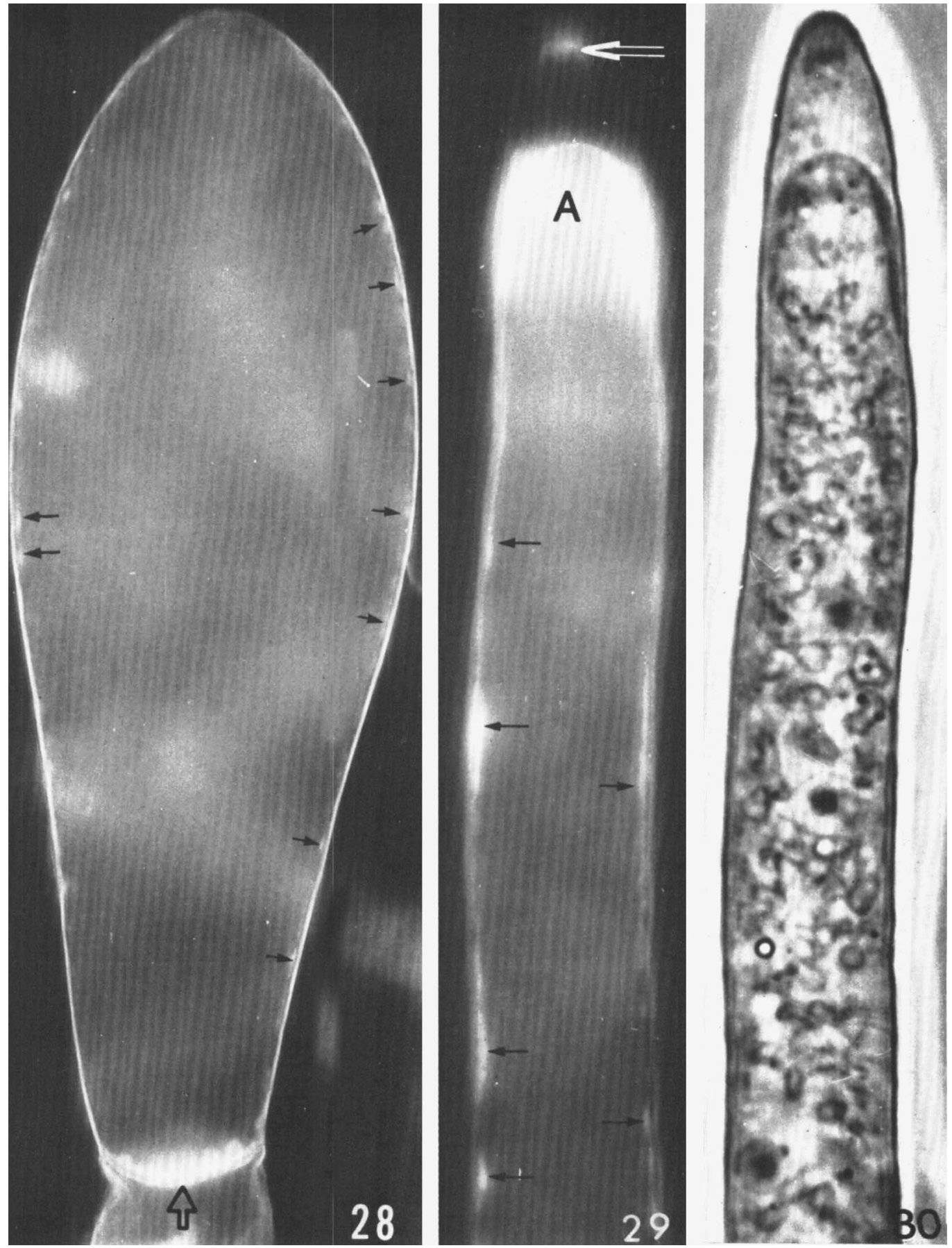

I. B. HEATH AND A. D. GREENWOOD 
lemmasome suggesting that these vesicles are becoming sequestered into the wall and thus becoming lomasomes. Ga. $\times 125,900$.

Fig. 14. S. ferax. A tubular lomasome in a hypha fixed in osmium tetroxide only. $\times 60,100$.

Fig. I5. S. ferax. Plasmalemmasome showing similar stain deposits over the intertubular matrix and the hyphal wall. Os. $\times 76,100$.

\section{Plate 7}

Fig. I6. S. ferax. Transverse section of a hyphal apex fixed in osmium tetroxide only. Note the irregular plasmalemma (arrow) and other irregular membranes which permeate the cytoplasm. Cf. Pl. 2, fig. 4. $\times 95,000$.

Fig. 17. S. ferax. Detail of typical irregular infolding of the plasmalemma (arrows) which may occur after osmium tetroxide fixation. $\times 95,000$.

\section{Plate 8}

Fig. 18, 19. S. ferax. Phase contrast micrographs of hyphal apices plasmolysed in $2 \mathrm{M}$-sucrose. The subapical cytoplasm has contracted away from the walls but that at the apex is apparently unaltered. Living material. $\times 970$.

Fig. 20. S. ferax. Typical subapical region of cytoplasm of a hypha grown at $30^{\circ}$. The mitochondria (M) are swollen and the endoplasmic reticulum (er) dilated. Note the large number of vesicles, with ribosomes, lying between the plasmalemma (arrowed) and the wall (w). Ga. $\times 21,600$.

Fig. 21. S. ferax. Primary cyst. Section treated with the PASH reagents. Note the heavy silver deposit over the wall (w) and intervesicular region of the plasmalemmasome (P). Ga. $\times 77,200$.

\section{Plate 9}

Fig. 22 and 23.S. ferax. Phase contrast(fig. 22) and fluorescence (fig. 23) micrographs showing strong fluorescence in the walls of the discharged sporangium $\left(\mathbf{S}_{1}\right)$ and increased intensity in the developing sporangium $\left(\mathrm{S}_{2}\right)$. Living material incubated in SITS. $\times$ I022.

Fig. 24 and 25. S. ferax. Vegetative hyphal apex showing apical fluorescence and patches of subapical staining (arrows) which do not correspond to any detectable structure in the phase contrast micrograph (fig. 24). Living hyphae incubated in SITS. $\times 2975$.

Fig. 26 and 27. S. ferax. Typical phase contrast (fig. 26) and fluorescence micrographs of a vegetative hyphal apex with strong apical fluorescence decreasing subapically with patches of increased intensity probably corresponding to plasmalemmasomes or lomasomes (arrows). Living hyphae incubated in SITS. $\times 1905$.

\section{Plate io}

Fig. 28. S. ferax. SITS stained discharged sporangium showing uniform fluorescence on the wall with areas of increased intensity on the basal cross wall (open arrow) and along the inner side of the sidewalls (small arrows). These latter areas probably correspond to lomasomes since there is no cytoplasm remaining in a discharged sporangium. $\times 820$.

Fig. 29 and 30. S. ferax. Interhyphal hypha stained with SITS reagent. Part of the moribund apex shows fluorescence (open arrow) but the most intense region is at the young apex (A). Note the subapical fluorescing areas (small arrows) which correspond partially to dense areas in fig. 30. These may indicate membranous material trapped between the young and old walls (cf. Pl. 2, fig. 5.). $\times 2675$. 